\title{
Antiviral effect of persimmon (Diospyros kaki Thunb. cv. Cheongdo-Bansi) extracts on murine norovirus
}

\author{
Jaein Choe ${ }^{1}$, Hyeju Jung ${ }^{1}$, Changsun Choi ${ }^{2}$, Mi-Kyung Park ${ }^{1 *}$ \\ ${ }^{1}$ School of Food Science and Biotechnology, Kyungpook National University, Daegu 41566, Korea \\ ${ }^{2}$ Department of Food and Nutrition, Chung-Ang University, Anseong 17546, Korea
}

\section{청도반시 추출물의 murine norovirus에 대한 항바이러스 효과}

\author{
최재인 ${ }^{1} \cdot$ 정혜주 $^{1} \cdot$ 최창순 $^{2} \cdot$ 박미경 $^{1 *}$ \\ 1경북대학교 식품공학부, ${ }^{2}$ 중앙대학교 식품영양학과
}

\begin{abstract}
Norovirus infections are one of the most significant causes of foodborne outbreaks worldwide. This study aimed to investigate the antiviral effects of persimmon (Diospyros kaki Thunb. cv. Cheongdo-Bansi) extracts on murine norovirus (MNV). Persimmon extracts obtained by solvent extraction and squeezing, prior to freeze-drying were evaluated by determining the yield and tannin contents. The cytotoxicity and antiviral effect of persimmon extracts were determined using a 3-(4,5-dimethylthiazol-2-yl)-2,5-diphenyltetrazolium bromide (MTT) assay and a timeof-addition assay, respectively. The yield and tannin content were in following order: methanol $>$ water $>$ ethanol $>$ acetone $>$ juice extracts and juice $>$ acetone $>$ water $>$ ethanol $>$ methanol extracts, respectively. The concentrations of methanol, ethanol, acetone, water, and juice extracts were determined to be $800,800,600,200$, and $400 \mu \mathrm{g} / \mathrm{mL}$, respectively. The MNV titer was significantly reduced by $1.65 \mathrm{log}$ plaque forming unit (PFU)/mL with $18 \%$ reduction in plaque formation in group pre-treated with water extract. Furthermore, the significant reductions in MNV titer by 2.14, 1.69, and $2.96 \log \mathrm{PFU} / \mathrm{mL}$ were observed in groups co-treated with acetone, water, and juice extracts, respectively with plaque formation inhibition of $22-40 \%$. However, there were no significant antiviral effects in the post-treated groups. This study suggests the potential use of persimmon extracts as anti-noroviral agents.
\end{abstract}

Key words : norovirus, persimmon (Diospyros kaki Thunb.), antiviral effect, time-of-addition assay, MTT asssy

\begin{abstract}
노로바이러스(Norovirus)는 Caliciviridae과에 속하는 7.5 $\mathrm{kb}$ 크기의 single positive stranded RNA 바이러스로 5개의 genogroups(G I-GV)으로 분류되며, 이 중 G I, GII, GIV가 인체 감염을 유발하는 것으로 알려져 있다(Bitler 등, 2013; Greening 등, 2016; Patel 등, 2009). 전 세계적으로 발생하는 식중독 사례의 약 $20 \%$ 가 노로바이러스에 의해 발생되고 있

\section{서 론}

*Corresponding author. E-mail : parkmik@knu.ac.kr, Phone :+82-53-950-5776, Fax : +82-53-950-6772

Received 09 March 2021; Revised 09 April 2021; Accepted 22 April 2021.

Copyright (c) The Korean Society of Food Preservation.

This is an Open Access article distributed under the terms of the Creative Commons Attribution Non-Commercial License (http://creativecommons.org/licenses/by-nc/4.0) which permits unrestricted non-commercial use, distribution, and reproduction in any medium, provided the original work is properly cited.
으며, 이로 인한 경제적 손실이 약 66조 원으로 추정되고 있 다(CDC, 2020). 미국의 경우, 해마다 평균 2,500건이 발생하 며, 전체 식중독 발병의 $58 \%$ 를 차지하고 있다(CDC, 2020). 국내도 최근 5년간(2015-2019) 노로바이러스로 인한 식중독 발병률이 전체 식중독의 약 $32 \%$ (평균 52건, 환자수 1,115 명) 로 가장 높은 비율을 차지하고 있다(MFDS, 2020). 노로바이 러스로 인한 식중독은 오염된 식품이나 물이 주원인이며, 감 염된 환자와의 접촉을 통해 전파되기도 한다(Patel 등, 2009; 
Richards 등, 2012). 노로바이러스에 감염되면 오심, 구토, 설 사, 복통의 주요 증상을 나타내며, 대부분은 1-2일 후에 자연 적으로 회복되나, 어린이, 노약자, 면역력이 약한 환자 등의 경우, 구토와 설사로 인해 심한 탈수 증세가 나타나 사망으로 이어질 수도 있다(Trivedi 등, 2013). 따라서, 노로바이러스 감염을 막기 위해서는 이를 예방하거나 제어하는 방법이 절 실히 필요하며, 이를 위해 항노로바이러스 효과를 나타내는 식품소재의 연구가 매우 중요하다.

인체 노로바이러스는 현재의 cell culture system에서는 배 양이 불가하므로, Caliciviridae과에 속하면서 노로바이러스 와 유전학적, 형태학적, 생화학적 특성이 유사한 murine norovirus-1(MNV), feline calicivirus-F9(FCV), MS2 bacteriophage 등이 항노로바이러스 연구에 활용되고 있다 (Hirneisen 등, 2013; Lee 등, 2011). 현재까지 국내에서 보고 된 항노로바이러스 효과 검증을 위한 연구로 레몬그라스 (Cymbopogon citrats)로부터 추출한 에센셜 오일의 $\mathrm{MNV}$ 에 대 한 항노로바이러스 효과(Kim 등, 2017)와 홍삼(Panax ginseng) 추출물(Lee 등, 2011)과 복분자(Rubus coreamus) 씨 추출물(Lee 등, 2016)의 MNV와 FCV에 대한 항노로바이러스 효과가 보고 되었다. 또한, 국외에서는 크랜베리(Vaccinium macrocarpon) 주 스(Su 등, 2010), 포도(Vitis vinifera)씨 추출물(Joshi 등, 2015), 녹차(Camellia sinensis) 추출물(Randazzo 등, 2017) 의 $\mathrm{MNV}$ 와 $\mathrm{FCV}$ 에 대한 항바이러스 효과가 보고되었다. 또 한, Ueda 등(2013)은 MNV와 FCV를 대상으로 아카시아 (Robinia pseudoacacia) 추출물, 커피(Coffea arabica) 추출 물, 녹차(Camellia sinensis) 추출물의 항노로바이러스 효과 를 검증하기도 하였다.

감(persimmon)은 그 학명이 Diospyros kaki Thunb.로 감 나무과(Ebenaceae)에 속하고, 약 1,000 여 종이 보고되고 있 으며, 한국, 중국, 일본 등이 원산지로 알려져 있다. 특히, 비 타민 $\mathrm{A}, \mathrm{B}, \mathrm{C}$ 와 탄닌(tannin), 갈산(gallic acid), 카테킨 (catechin), 에피카테킨(epicatechin), 퀘세틴(quercetin), 클로 로겐산(chlorogenic acid) 등과 같은 폴리페놀 화합물이 다량 함유되어 있어 숙취 해소와 기침 치료 등에 효과가 있으며, 항산화, 알코올대사 촉진, 지질대사 개선 등의 효과로 인해 민 간과 한방에서 활용되어 왔다(Bian 등, 2015; Kim 등, 2011). 현재까지 감에 대한 연구로 식중독균을 대상으로 항균효과 (Arakawa 등, 2014; Sung 등, 2012)에 관한 연구가 일부 진행 되기는 하였으나, 최근에 문제가 되고 있는 항노로바이러스에 관한 연구는 거의 전무한 상황이다. 따라서 본 연구에서는 경북 청도 지역 특산품인 청도반시(D. kaki T. cv. Cheongdo-Bansi) 추출물 및 착즙물의 $\mathrm{MNV}$ 에 대한 항노로바이러스 효과를 검 증하고자 한다.

\section{재료 및 방법}

\section{청도반시 추출물과 착즙물 제조 및 수율 측정}

청도반시는 8 월 말에 적과한 미숙과로 경상북도 청도군 [(주)행복한감]에서 제공 받아 추출과 착즙의 두 가지 방법으 로 시료를 제조하였다. 미숙과를 세척 후, 꼭지를 제거하고 5 $\mathrm{mm}$ 두께로 절단하여 농산물 건조기(KED-132A, Kiturami Co., Seoul, Korea)로 건조한 뒤, 분쇄기(SNSG-1002SS, Hanil Electronic Inc., Seoul, Korea)를 이용하여 감 분말을 제조하 였다. 추출물은 감 분말 $50 \mathrm{~g}$ 에 $500 \mathrm{~mL}$ 의 $80 \%$ 메탄올, $80 \%$ 아세톤, $95 \%$ 에탄올, 그리고 물을 가하여 각각 $150 \mathrm{rpm}$ 에서 24시간 동안 추출하였고, 착즙물 제조를 위해서는 동량의 미숙 과를 착즙기(SJM-7500, Sungwon System Co., Ansan, Korea) 로 착즙하였다. 추출물과 착즙물은 각각 여과지(Whatman No.4) 로 여과하여 회전식 진공농축기(N-1300, Eyela, Tokyo, Japan)로 농축한 뒤, 동결건조기(MCFD 8518, Ilshinbiobase Co., Yanju, Korea)로 건조하였다. 추출물과 착즙물의 수율 은 각각 추출 전 청도반시 분말의 중량 또는 착즙물의 중량에 대한 동결 건조 후 중량 변화를 측정하여 백분율(\%)로 나타 내었다(Jang 등, 2010).

\section{탄닌 함량 측정}

청도반시 추출물 및 착즙물의 탄닌 함량은 vanillin법(Price 등, 1978)으로 측정하였다. $1 \mathrm{~mL}$ 의 추출물과 착즙물에 각각 $5 \mathrm{~mL}$ 의 $1 \%$ vanillin 시약(Sigma-Aldrich Co., St. Louis, $\mathrm{MO}, \mathrm{USA}$ )을 첨가하여 $30^{\circ} \mathrm{C}$ 에서 20 분 동안 반응시킨 후, 분 광광도계(Optizen 2120UV, Mecasys Co., Daejeon, Korea) 를 이용하여 $500 \mathrm{~nm}$ 에서 흡광도를 측정하였다. (+)-Catechin hydrate(Sigma-Aldrich Co.)를 표준물질로 사용하였으며, 탄 닌 함량은 시료 $1 \mathrm{~g}$ 당 $\mathrm{mg} \mathrm{CE}(\mathrm{mg}$ of catechin equivalents)로 나타내었다.

\section{세포 배양 및 바이러스 증식}

RAW 264.7 세포와 norovirus surrogate인 murine norovirus-1 $(\mathrm{MNV})$ 은 중앙대학교 식품영양학과 식품안정성 연구실로부 터 제공받아 실험에 사용하였다. RAW 264.7 세포는 $1 \%$ penicillin/streptomycin(Hyclone Inc., Logan, UT, USA)과 10\% fetal bovine serum(Sigma-Aldrich Co.)이 첨가된 Dulbecco's Modified Eagles Medium(DMEM; Welgene Inc., Daegu, Korea)를 사용하여 $37^{\circ} \mathrm{C}, 5 \% \mathrm{CO}_{2}$ 의 조건에서 배양하였다. $\mathrm{MNV}$ 증식은 RAW 264.7 세포에 접종하여 48시간 배양 후 동결과 녹임을 3회 반복하여 RAW 264.7 세포를 완전히 파 괴시킨 다음, 배양액을 회수하여 $1,500 \times g$ 에서 15 분 동안 원 심 분리하였고, 상층액을 $-70^{\circ} \mathrm{C}$ 에 보관하여 사용하였다. 


\section{청도반시 추출물 및 착즙물의 세포독성 측정}

청도반시 추출물 및 착즙물이 RAW 264.7 세포에 미치 는 독성을 확인하기 위해 3-(4,5-dimethylthiazol-2-yl)-2,5diphenyltetrazolium bromide(MTT) assay를 실시하였다. 96well plate에 RAW 264.7 세포를 $10^{5}$ cells $/ \mathrm{mL}$ 로 분주하여 24 시간 배양하였으며, 세포 단층이 형성되면 메탄올, 에탄올, 아세톤, 물 추출물 및 착즙물을 각각 $100,200,400,600,800$ $\mu \mathrm{g} / \mathrm{mL}$ 의 농도로 분주하여 다시 24 시간 동안 배양하였다. 배 지 제거 후, $100 \mu \mathrm{L}$ 의 MTT $(5 \mathrm{mg} / \mathrm{mL})$ 용액을 분주하여 $37^{\circ} \mathrm{C}$ 에서 1 시간 동안 반응시켰다. MTT 용액을 제거하고 $100 \mu \mathrm{L}$ 의 DMSO를 분주하여 MTT-formazan 결정체를 녹인 후, 흡 광도 기기(Multiskan FC Microplate Photometer, Thermo Fisher Scientific Inc., Waltham, MA, USA)로 $595 \mathrm{~nm}$ 에서 흡광도를 측정하였다. 추출물 또는 착즙물을 처리하지 않은 세포를 대조군(control)으로 대조군에 대한 세포 생존율을 백 분율(\%)로 나타내었다.

\section{청도반시 추출물 및 착즙물의 항노로바이러스 효과 검증}

항노로바이러스 효과 검증을 위한 메탄올, 에탄올, 아세톤, 물 추출물 및 착즙물의 최종 농도는 세포 독성 실험 결과를 토대로 각각 $800,800,600,200,400 \mu \mathrm{g} / \mathrm{mL}$ 로 선정하였다. 항노로바이러스 효과의 검증은 추출물 및 착즙물의 첨가 시 점을 기준으로 pre-treatment(바이러스 접종 전 추출물 및 착 즙물의 처리), co-treatment (바이러스와 추출물 및 착즙물의 동시 접종), post-treatment(바이러스 접종 이후 추출물 및 착 즙물의 처리)로 나누어 분석하였다(Seo 등, 2016). 첫째, 6-well plate에 RAW 264.7 세포를 $10^{5}$ cells $/ \mathrm{mL}$ 로 분주하여 $37^{\circ} \mathrm{C}, 5 \% \mathrm{CO}_{2}$ 에서 배양한 후, 세포의 단층형성을 현미경으 로 관찰하였다. Pre-treatment 효과 검증을 위해 상기에 언급 된 농도의 추출물 및 착즙물이 함유된 DMEM을 세포 단층 을 형성한 RAW 264.7 세포에 $100 \mu \mathrm{L}$ 씩 처리하고, $37^{\circ} \mathrm{C}, 5 \%$ $\mathrm{CO}_{2}$ 에서 1시간 동안 배양한 뒤, $\mathrm{MNV}(7.3 \log \mathrm{PFU} / \mathrm{mL})$ 를 $\mathrm{DMEM}$ 으로 십진 희석하여 $100 \mu \mathrm{L}$ 씩 접종하고 $37^{\circ} \mathrm{C}, 5 \%$ $\mathrm{CO}_{2}$ 에서 2시간 동안 배양하였다. Co-treatment 효과 검증을 위해 $\mathrm{MNV}$ 와 상기에 언급된 농도의 추출물 및 착즙물의 혼 합액을 $100 \mu \mathrm{L}$ 씩 처리한 뒤, $37^{\circ} \mathrm{C}, 5 \% \mathrm{CO}_{2}$ 에서 2 시간 동안 배양하였다. Post-treatment 효과 검증을 위해 세포 단층을 형 성한 RAW 264.7 세포에 DMEM으로 십진 희석한 MNV를 $100 \mu \mathrm{L}$ 씩 접종하여 $37^{\circ} \mathrm{C}, 5 \% \mathrm{CO}_{2}$ 에서 2시간 동안 배양한
뒤, MNV가 함유된 DMEM을 제거하였고, $100 \mu \mathrm{L}$ 의 추출물 또는 착즙물을 상기에 언급된 농도로 각각 처리하여 1 시간 동안 배양하였다. 배양 후 모든 처리구는 $0.6 \%$ agarose가 함 유된 DMEM을 첨가한 후 48시간 동안 배양하였고, plaque 형성 여부가 관찰되면 $10 \%$ formalehyde(Samchun Chemicals, Pyeongtaek, Korea)을 첨가하여 상온에서 4시간 동안 세포를 고정하였다. Agar overlay medium을 제거하고, crystal violet 용액으로 염색하여 plaque를 계수하였다. 추출물 및 착즙물 을 처리하지 않은 $\mathrm{DMEM}$ 및 $\mathrm{MNV}$ 를 각각 음성대조군 (negative control)과 양성대조군(positive control)으로 하였 으며, 추출물 및 착즙물의 항노로바이러스 효과는 양성대조 군에 대한 플라크 형성 유무를 백분율(\%)로 나타내었다.

\section{통계분석}

모든 데이터는 3 회 반복하여 평균 \pm 표준편차로 나타내었으 며, 통계 분석은 GraphPad and InStat v.3 programs(GraphPad, San Diego, CA, USA)를 이용하였다. 각 평균값의 차이를 검 증하기 위하여 t-test와 one-way ANOVA 분석을 실시하였으 며, Ducan의 다범위 검정(Ducan's multiple range test)를 통 하여 $\mathrm{p}<0.05$ 의 수준에서 유의차를 검증하였다.

\section{결과 및 고찰}

\section{청도반시 추출물 및 착즙물의 수율}

청도반시 추출물 제조를 위한 용매 조건은 선행연구(Akter 등, 2010; Jang 등, 2010)를 참고로 하여 $80 \%$ 메탄올, $95 \%$ 에탄올, $80 \%$ 아세톤, 물로 선정하였다. 용매 추출물과 착즙 물을 동결 건조하여 각각의 수율을 비교 검토한 결과(Table $1)$, 메탄올 추출물 > 물 추출물 > 에탄올 추출물 > 아세톤 추출물 > 착즙물의 순으로 높았다. 이 중 메탄올이 $37.74 \%$ 로 가장 높은 반면, 착즙물은 $7.25 \%$ 로 가장 낮은 추출 수율을 보여 주었다. Jang 등(2010)은 부유 단감(D. kaki T. cv. Fuyu) 을 부위별(과육, 껍질, 씨, 꼭지)로 구분하여 이들을 메탄올, 에탄올, 아세톤, 물로 각각 추출하였고, 수율을 검토한 결과, 과육 추출물의 수율이 껍질, 씨, 꼭지보다 유의적으로 높았으 며 $(\mathrm{p}<0.05)$, 메탄올 $(91.02 \%)>$ 에탄올 $(75.95 \%)>$ 물 $(17.60 \%)$ $>$ 아세톤(11.64\%)의 순으로 보고되었다. 추출 용매에 따른 수율이 메탄올에서 가장 높고, 아세톤에서 가장 낮다는 점에 서 본 연구와 유사함을 보여 주고 있다.

Table 1. Yields of persimmon (D. kaki T. cv. Cheongdo-Bansi) extracts

\begin{tabular}{cccccc}
\hline & Methanol & Ethanol & Acetone & Water & Juice \\
\hline Yield (\%) & 37.74 & 14.87 & 7.41 & 15.38 & 7.25 \\
\hline
\end{tabular}




\section{청도반시 추출물 및 착즙물의 탄닌 함량}

탄닌은 항바이러스 효과를 나타내는 주요한 성분(Kim 등, 1995)이므로 추출물과 착즙물의 탄닌 함량을 vanillin법으로 측정하였고 catechin을 표준물질로 하여 검량선을 작성한 결과 (Fig. 1), 회귀식은 $\mathrm{y}=0.42 \mathrm{x}+0.05$ 이었으며, 상관계수 $\left(\mathrm{R}^{2}\right) 0.99$ 로 나타났다. 검출한계(limit of detection, LOD)와 정량한계 (limit of quantitation, LOQ)는 식품의약처의 의약품 및 시험 방법 validation 가이드라인에 따라 각각 $3.3 \times \sigma$ (반응의 표준 편차)/S(표준곡선의 기울기), $10 \times \sigma / \mathrm{S}$ 로 결정하였으며, 그 결 과 $\mathrm{LOD}$ 와 $\mathrm{LOQ}$ 는 각각 $0.23,0.68 \mathrm{mg} / \mathrm{mL}$ 로 나타났다. $0.25-$ $2.00 \mathrm{mg} / \mathrm{mL}$ 의 농도 범위에서 회수율(recovery)은 79.68$121.43 \%$ 로 상대표준편차(relative standard deviation, RSD) 는 1.14-6.47\%로 결정되었다. 표준곡선으로부터 추출물 및 착즙물의 탄닌 함량을 측정한 결과(Table 2), 착즙물 > 아세 톤 추출물 $>$ 물 추출물 $>$ 에탄올 추출물 $>$ 메탄올 추출물 순으로 착즙물에서 $36.13 \pm 0.17 \mathrm{mg} \mathrm{CE} / \mathrm{g}$ 으로 유의적으로 가 장 높았으며, 아세톤 추출물, 물 추출물 순으로 높은 탄닌 함 량을 나타내었다 $(\mathrm{p}<0.05)$. 반면, 에탄올 추출물과 메탄올 추출 물에서는 유의적으로 낮은 탄닌 함량이 측정되었다 $(\mathrm{p}<0.05)$. 이는 수율과는 상반되는 결과로 $7.25 \%$ 로 가장 낮은 수율을 보였던 착즙물에서 유의적으로 높은 탄닌 함량이 측정된 반

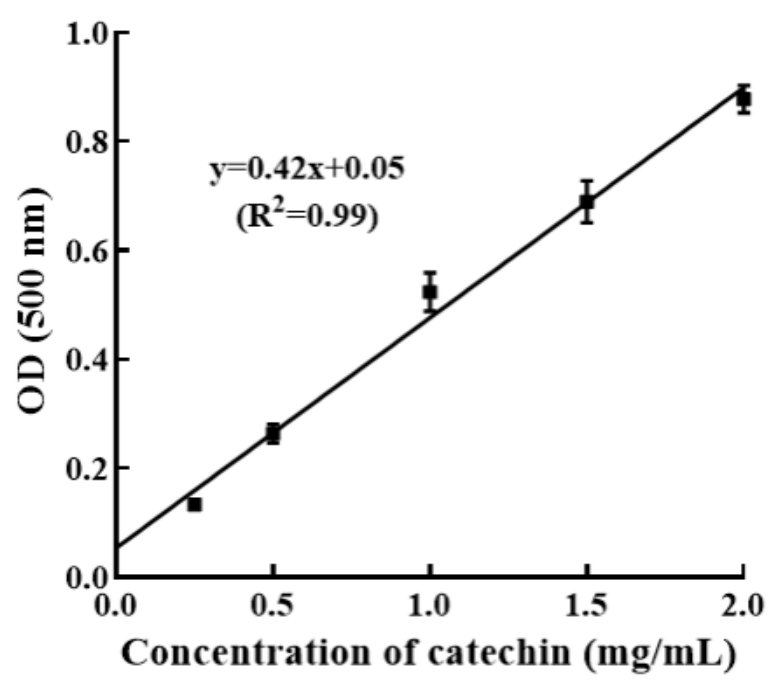

Fig. 1. Standard curve of $(+)$-catechin hydrate.
면, $37.74 \%$ 로 가장 높은 수율을 보였던 메탄올 추출물에서 가장 낮은 탄닌 함량을 나타내었다.

$\operatorname{Sim}$ 등(2016)은 본 연구 결과와 유사하게 청도반시 $(D$. kaki. T.) 미숙과의 물 추출물의 탄닌 함량을 $2.88 \mathrm{mg} / \mathrm{g}$ 으로 보고한 반면, $\mathrm{Kim}$ 등(2015)은 둥시(D. kaki T.) 에탄올 추출 물의 탄닌 함량을 $0.18 \mathrm{mg} / \mathrm{g}$ 으로 보고하였다. 탄닌의 함량은 감의 품종 및 수확 시기 그리고 추출용매에 따라 그 범위가 다양하며, 청도반시 에탄올 추출물의 탄닌 함량 $(0.08 \pm 0.03$ $\mathrm{mg} / \mathrm{g}$ )이 Kim 등(2015)의 연구보다는 2 배 정도 낮게 검출된 이유는 감의 품종 및 수확 시기 차이에 따른 결과로 해석된다 (Bian 등, 2015).

\section{청도반시 추출물 및 착즙물의 처리에 따른 세포 독성}

청도반시 추출물 및 착즙물이 RAW 264.7 세포 생존율에 미치는 영향을 MTT assay로 분석하였고, 그 결과는 Fig. 2와 같다. 메탄올 추출물(Fig. 2A)의 세포 생존율은 농도 의존적 으로 감소하는 경향 $(600 \mu \mathrm{g} / \mathrm{mL}$ 의 농도 제외)을 보여 주었으 며, $800 \mu \mathrm{g} / \mathrm{mL}$ 의 농도에서는 대조구 대비 $86.19 \pm 5.53 \%$ 로 유 의적인 차이를 보여 주었다 $(\mathrm{p}<0.05)$. 이에 비해 에탄올 추출 물(Fig. 2B)의 세포 생존율은 증감을 유지하다가 $600 \mu \mathrm{g} / \mathrm{mL}$ 와 $800 \mu \mathrm{g} / \mathrm{mL}$ 의 농도에서는 $91.75 \pm 6.98 \%$ 와 $83.63 \pm 2.61 \%$ 로 대조군과 유의적인 차이를 보여 주었다 $(\mathrm{p}<0.05)$. 그 외에 아 세톤 추출물(Fig. 2C), 물 추출물(Fig. 2D), 착즙물(Fig. 2E) 모두 세포 생존율은 추출물의 농도가 증가함에 따라 감소하 는 경향을 보여 주었다. 선행 연구 결과를 토대로(Inwasawa 등, 2013; Yoo 등, 2014) $80 \%$ 이상의 세포 생존율을 보이는 추출물 및 착즙물의 농도를 cut-off 값으로 선정하였고, 항노 로바이러스 효과 검증을 위한 추출물 및 착즙물의 최종 농도로 메탄올과 에탄올은 각각 $800 \mu \mathrm{g} / \mathrm{mL}$, 아세톤은 $600 \mu \mathrm{g} / \mathrm{mL}$, 물 추출물 및 착즙물은 $200 \mu \mathrm{g} / \mathrm{mL}$ 와 $400 \mu \mathrm{g} / \mathrm{mL}$ 로 결정하였다.

\section{청도반시 추출물 및 착즙물의 항노로바이러스 효과}

청도반시 추출물 및 착즙물의 항노로바이러스 효과는 대조 구 대비 노로바이러스 플라크 형성율과 감소된 노로바이러스 의 농도를 Fig. 3 과 Table 3에 각각 나타내었다. 바이러스 접종 전 청도반시 추출물 및 착즙물을 세포에 처리(pre-treatment)한 결과, 메탄올, 에탄올, 아세톤, 물 추출물 및 착즙물 처리구에 서 노로바이러스의 플라크 형성율 및 감소된 노로바이러스

Table 2. Tannin content of persimmon (D. kaki T. cv. Cheongdo-Bansi) extracts for different solvents

\begin{tabular}{cccccc}
\hline & Methanol & Ethanol & Acetone & Water & Juice \\
\hline $\begin{array}{c}\text { Tannin content } \\
(\mathrm{mg} \mathrm{CE} / \mathrm{g})\end{array}$ & $0.04 \pm 0.01^{\mathrm{d} 1)}$ & $0.08 \pm 0.03^{\mathrm{d}}$ & $6.13 \pm 0.55^{\mathrm{b}}$ & $2.32 \pm 0.03^{\mathrm{c}}$ & $36.13 \pm 0.17^{\mathrm{a}}$ \\
\hline
\end{tabular}

${ }^{1)}$ Values are mean $\pm \mathrm{SD}(\mathrm{n}=3)$. The letters $\left({ }^{\mathrm{a}-\mathrm{d}}\right)$ indicate significant difference within row by one-way ANOVA $(\mathrm{p}<0.05)$. 
(A)

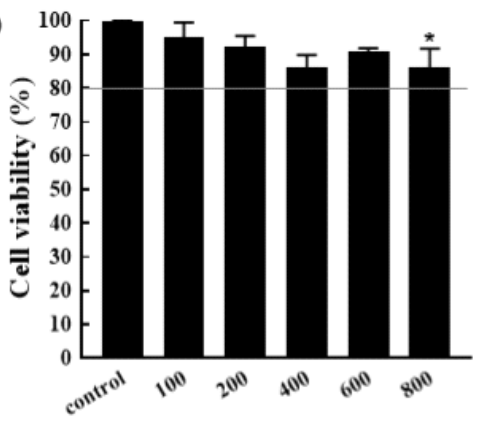

Concentration of extract $(\mu \mathrm{g} / \mathrm{mL})$

(D)

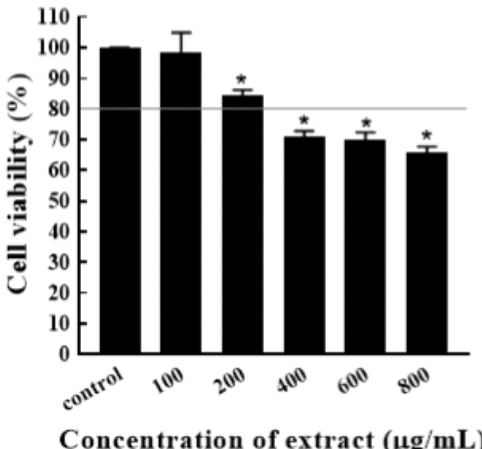

(B)

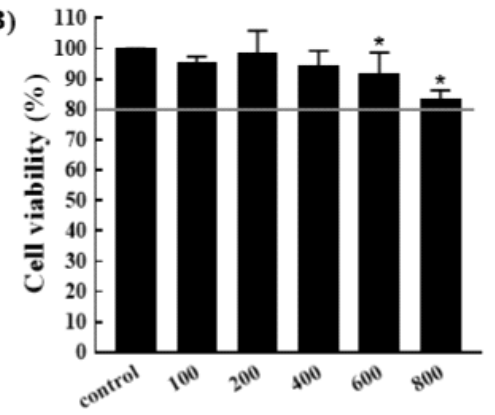

Concentration of extract $(\mu \mathrm{g} / \mathrm{mL})$

(E)

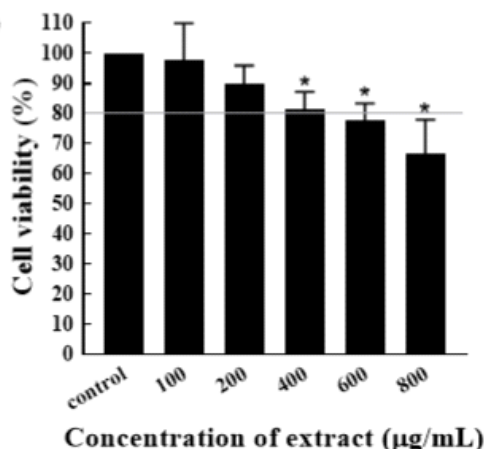

(C)

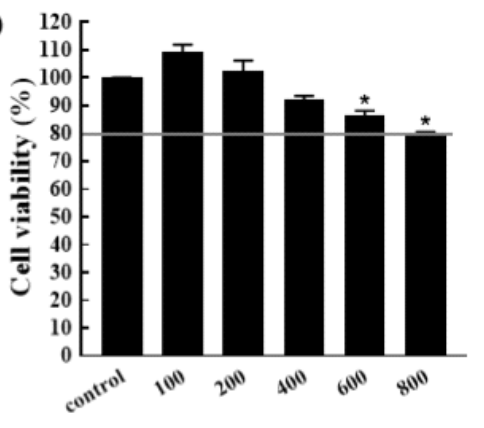

Concentration of extract $(\mu \mathrm{g} / \mathrm{mL})$

Fig. 2. Cell viability of RAW 264.7 cells treated with (A) methanol, (B) ethanol, (C) acetone, (D) water, and (E) juice extracts from persimmon (D. kaki T. cv. Cheongdo-Bansi).

The symbol $\left(^{*}\right)$ indicates the significant difference between control and extract treatments by $\mathrm{t}$-test $(\mathrm{p}<0.05)$.

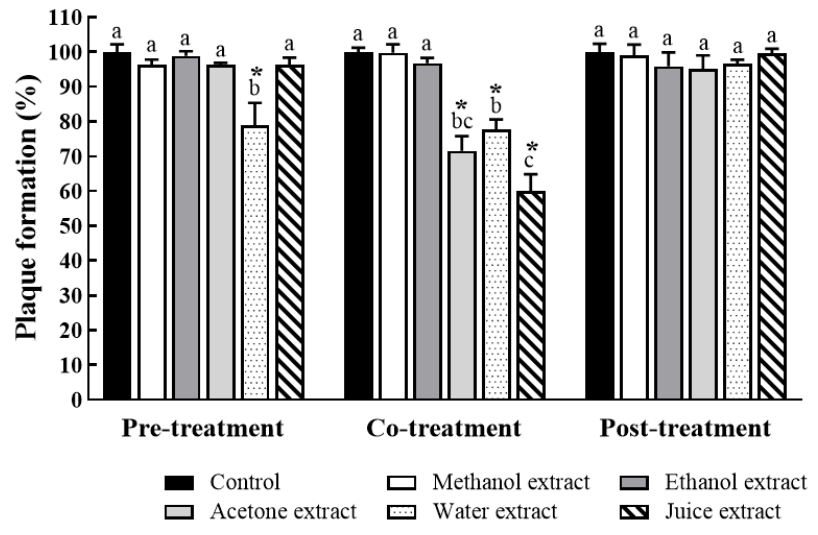

Fig. 3. Antiviral effects of persimmon (D. kaki T. cv. CheongdoBansi) extracts on murine norovirus.

The symbol $\left(^{*}\right)$ indicates the significant differences between control and each extract treatment by $\mathrm{t}$-test $(\mathrm{p}<0.05)$.

The letter $\left({ }^{\mathrm{a}-\mathrm{c}}\right)$ indicates the significant differences among extract treatments at the same time period by one-way ANOVA $(p<0.05)$

The concentration of methanol, ethanol, acetone, water, and juice extracts were $800,800,600,200$, and $400 \mu \mathrm{g} / \mathrm{mL}$, respectively.

농도는 각각 $96.19 \pm 1.59 \%$ 와 $0.29 \pm 0.19 \log \mathrm{PFU} / \mathrm{mL}, 98.45 \pm$ $1.33 \%$ 와 $0.11 \pm 0.07 \log$ PFU $/ \mathrm{mL}, 96.35 \pm 0.53 \%$ 와 $0.27 \pm 0.03$ $\log \mathrm{PFU} / \mathrm{mL}, 82.40 \pm 6.64 \%$ 와 $1.65 \pm 0.43 \log \mathrm{PFU} / \mathrm{mL}$, $96.26 \pm 2.05 \%$ 와 $0.27 \pm 0.06 \log \mathrm{PFU} / \mathrm{mL}$ 로 나타났다. 특히, 물 추출물 처리구에서는 노로바이러스의 플라크 형성율과 감소 된 농도는 약 $82 \%$ 와 $1.65 \log \mathrm{PFU} / \mathrm{mL}$ 로 대조구 대비 유의 적으로 감소되는 효과를 보여 주었으나 $(\mathrm{p}<0.05)$, 메탄올, 에 탄올, 아세톤 추출물 및 착즙물 처리구에서는 유의적인 차이 가 없었다 $(\mathrm{p}<0.05)$. 감 추출물과 착즙물의 탄닌 함량(Table 2$)$ 은 착즙물 $>$ 아세톤 추출물 $>$ 물 추출물 $>$ 에탄올 추출물 $>$ 메탄올 추출물 순이었으나, 본 연구의 결과는 물 추출물 처리 구에서 유의적으로 가장 높았으며, 다른 추출물에서는 거의 효 과가 없는 것으로 나타났다. 탄닌 함량과 항바이러스의 비례적 상관관계에 관해 일부 연구(Fukuchi 등, 1989; Kammimoto 등, 2014)가 보고되긴 하였으나, 이들 모두 pre-treatment 시 점이 아닌 co-treatment 시점에서의 효과 검증 결과를 토대로 한 것이므로 본 연구 결과와 상관성은 없다고 사료된다. 즉, pre-treatment는 감 추출물과 착즙물이 노로바이러스와 결합 하는 RAW 264.7 세포의 receptor에 미치는 영향을 검토하는 것으로 물 추출물이 세포의 receptor에 영향을 미쳐 노로바이 러스의 결합을 억제함으로써 항노로바이러스 효과를 갖는 것 으로 사료된다(Lee 등, 2011). 
Table 3. Reduction of murine norovirus titer $(\log \mathrm{PFU} / \mathrm{mL})$ after persimmon ( $\mathrm{D}$. kaki T. cv. Cheongdo-Bansi) extracts treatment

\begin{tabular}{cccc}
\hline Extract & Pre-treatment & Co-treatment & Post-treatment \\
\hline Methanol & $0.29 \pm 0.19^{1) \mathrm{b} 2)}$ & $0.02 \pm 0.17^{\mathrm{d}}$ & $0.07 \pm 0.16^{\mathrm{a}}$ \\
Ethanol & $0.11 \pm 0.07^{\mathrm{b}}$ & $0.25 \pm 0.10^{\mathrm{d}}$ & $0.30 \pm 0.28^{\mathrm{a}}$ \\
Acetone & $0.27 \pm 0.03^{\mathrm{b}}$ & $2.14 \pm 0.20^{\mathrm{b}}$ & $0.37 \pm 0.30^{\mathrm{a}}$ \\
Water & $1.65 \pm 0.43^{\mathrm{a}}$ & $1.69 \pm 0.16^{\mathrm{c}}$ & $0.25 \pm 0.19^{\mathrm{a}}$ \\
Juice & $0.27 \pm 0.06^{\mathrm{b}}$ & $2.96 \pm 0.16^{\mathrm{a}}$ & $0.04 \pm 0.03^{\mathrm{a}}$ \\
\hline
\end{tabular}

${ }^{1)}$ Data was expressed in log plaque forming units $/ \mathrm{mL}$. Values are mean $\pm \mathrm{SD}(\mathrm{n}=3)$.

${ }^{2)}$ The letters $\left({ }^{\mathrm{a}-\mathrm{d}}\right)$ indicate significant difference within column by one-way ANOVA $(\mathrm{p}<0.05)$.

청도반시 추출물 및 착즙물을 노로바이러스에 동시에 접 종(co-treatment)한 결과, 아세톤 추출물, 물 추출물, 착즙물의 처리구에서 노로바이러스 형성율은 각각 대조구 대비 $71.50 \pm$ $4.24 \%, 77.62 \pm 2.92 \%, 59.76 \pm 2.36 \%$ 로 나타났으며, 감소된 노로바이러스 농도는 각각 $2.14 \pm 0.20 \log \mathrm{PFU} / \mathrm{mL}, 1.69 \pm$ $0.16 \log \mathrm{PFU} / \mathrm{mL}, 2.96 \pm 0.16 \log \mathrm{PFU} / \mathrm{mL}$ 로 유의적인 감소 를 보여주었다 $(\mathrm{p}<0.05)$. 반면, 메탄올과 에탄올 추출물 처리 구는 대조구 대비 유의적인 차이를 나타내지 않았으므로 항 노로바이러스 효과가 확인되지 않았다. 본 연구에서 가장 높 은 탄닌 함량을 보인 착즙물 처리구에서 유의적으로 높은 항 노로바이러스 효과를 나타냈으며, 이는 기존의 연구들 (Fukuchi 등, 1989; Kammimoto 등, 2014)의 결과와 일치하 는 결과를 보여주고 있다. Fukuchi 등(1989)은 co-treatment 시점에서 탄닌 $(10 \mu \mathrm{g} / \mathrm{mL})$ 처리구가 herpes simplex virus (HSV-1)를 $3 \log \mathrm{PFU} / \mathrm{mL}$ 이상 저해시켰고, 처리된 탄닌이 세포와 바이러스의 흡착을 직접적으로 저해함으로써 항바이 러스 효과를 나타낸다고 보고하였다. Ueda 등(2014)은 co-treatment 시점에서 감 착즙물 처리구가 influenza virus의 감염을 약 $5.5 \log \mathrm{PFU} / \mathrm{mL}$ 저해시켰으며, 이는 감 착즙물의 탄닌이 influenza virus의 단백질과 상호작용하여 바이러스와 세포의 흡착을 저해한다고 보고하였다. 본 연구에서는 감 추 출물 및 착즙물의 탄닌 함량에 따라 항바이러스 효과의 유의 적인 차이를 보여주었으므로 탄닌이 바이러스가 세포로 흡착 하는 것을 저해하는 것으로 예측할 수 있다.

이에 비해, 바이러스 접종 이후 청도반시 추출물 및 착즙 물을 처리(post-treatment)한 결과, 메탄올, 에탄올, 아세톤, 물 추출물 및 착즙물의 처리구에서 노로바이러스 플라크 형 성율과 감소된 농도는 각각 $99.04 \pm 3.06 \%$ 와 $0.07 \pm 0.16 \mathrm{log}$ $\mathrm{PFU} / \mathrm{mL}, 95.86 \pm 4.00$ 와 $0.30 \pm 0.28 \log \mathrm{PFU} / \mathrm{mL}, 95.15 \pm$ $3.85 \%$ 와 $0.37 \pm 0.30 \log \mathrm{PFU} / \mathrm{mL}, 96.64 \pm 1.12 \%$ 와 $0.25 \pm 0.19$ $\log \mathrm{PFU} / \mathrm{mL}, 99.32 \pm 1.39 \%$ 와 $0.04 \pm 0.03 \log \mathrm{PFU} / \mathrm{mL}$ 로 확인 되었다. 감 추출물과 착즙물 모두 post-treatment 시점에서 노 로바이러스 농도의 감소는 보였으나 대조구 대비 유의적인 차
이는 나타나지 않았다. 이는 탄닌 $(10 \mu \mathrm{g} / \mathrm{mL})$ 의 post-treatment 가 HSV-1에 대해 항노로바이러스 효과를 보이지 않았다는 선행 연구와 유사한 경향을 보인다(Fukuchi 등, 1989).

현재까지 국제 저명 학술지에 감 추출물 및 착즙물 대상으 로 항바이러스 효과 관련된 논문이 극히 제한적이나, Ueda 등(2013)은 감 착즙물과 $\mathrm{MNV}$ 를 동시에 접종한 결과, $\mathrm{MNV}$ 의 농도가 대조구 대비 $4.3 \log \mathrm{PFU} / \mathrm{mL}$ 감소되었고, 본 연구 의 결과와 동일하게 감 착즙물이 노로바이러스와 세포와의 결합을 저해함으로써 항노로바이러스 효과를 나타냄을 보고 하고 있다. 그 외, Su 등(2011)의 연구에서는 포도 씨 에탄올 추출물을 $\mathrm{MNV}$ 와 동시에 접종한 결과, $\mathrm{MNV}$ 의 농도가 0.82-1.73 $\log \mathrm{PFU} / \mathrm{mL}$ 감소하는 효과를 확인하였다. 또한, Lee 등(2016)은 복분자 씨 에탄올추출물의 항노로바이러스 효과를 pre-treatment, co-treatment, post-treatment로 검증한 결과, $\mathrm{MNV}$ 의 농도가 각각 $3.03 \log \mathrm{PFU} / \mathrm{mL}, 3.93 \log$ $\mathrm{PFU} / \mathrm{mL}, 3.07 \log \mathrm{PFU} / \mathrm{mL}$ 감소됨을 확인하였다. 따라서, 청도반시 물 추출물과 아세톤 추출물 그리고 착즙물에서 포 도 씨 에탄올 추출물 및 복분자 에탄올 추출물의 항노로바이 러스 효과와 비견할만한 플라크 형성 감소를 확인할 수 있었 다. Kammimoto 등(2014)의 연구에서는 co-treatment 시점에 서 감 착즙물에 의해 MS2 phage가 약 $99.9 \%$ 감소되었고, 인 체 노로바이러스에도 $90 \%$ 의 감소율을 보여주었다. 또한, $\mathrm{Li}$ 등(2012)의 연구에서는 co-treatment 시점에서 포도 씨 추출물 에 의해 MNV에서는 $99.9 \%$, 인체 노로바이러스에서는 $99 \%$ 의 감소율을 보여주었다. Surrogate로 사용된 MS2 phage 및 $\mathrm{MNV}$ 와 인체 노로바이러스의 저감화에 대해 수치적인 차이 는 보였으나, 항노로바이러스 효과 자체에는 동일한 경향을 보여주었다. 따라서, 본 연구에서 MNV에 대해 효과를 보인 감 추출물 및 착즙물은 인체 노로바이러스에서도 항노로바이 러스 효과를 보여줄 수 있을 것으로 예측된다. 이는 청도반시 추출물 및 착즙물을 대상으로 항노로바이러스 대응 기능성 소재로써의 응용가능성을 제시하였다. 


\section{요 약}

청도반시의 항노로바이러스 효과를 검증하기 위해 메탄 올, 에탄올, 아세톤, 물 추출물 및 착즙물을 제조하여 각각의 수율과 탄닌 함량을 분석한 결과, 수율은 메탄올 추출물 > 물 추출물 > 에탄올 추출물 > 아세톤 추출물 > 착즙물 순인 반면, 탄닌 함량은 착즙물 > 아세톤 추출물 > 물 추출물 > 에탄올 추출물 > 메탄올 추출물의 순으로 상반되는 결과를 보여주었다. MTT assay를 통한 세포 생존율 결과를 토대로 메탄올과 에탄올은 각각 $800 \mu \mathrm{g} / \mathrm{mL}$, 아세톤은 $600 \mu \mathrm{g} / \mathrm{mL}$, 물 추출물 및 착즙물은 $200 \mu \mathrm{g} / \mathrm{mL}$ 와 $400 \mu \mathrm{g} / \mathrm{mL}$ 로 항바이 러스 효과 검증을 위한 최종 농도로 결정하였다. $\mathrm{MNV}$ 에 대 한 항노로바이러스 효과를 time-of-addition assay로 분석한 결과, 바이러스 접종 전 추출물 및 착즙물을 세포에 처리한 pre-treatment에서 물 추출물 처리구가 항노로바이러스 효과 가 있음을 확인할 수 있었다. 또한, 추출물 및 착즙물과 바이 러스를 동시에 접종한 co-treatment에서 아세톤, 물 추출물 및 착즙물의 처리구의 플라크 형성율이 각각 $71.50 \pm 4.24 \%$, $77.62 \pm 2.92 \%, 59.76 \pm 2.36 \%$ 로 나타났으며, $2.14 \pm 0.20 \mathrm{log}$ $\mathrm{PFU} / \mathrm{mL}, 1.69 \pm 0.16 \log \mathrm{PFU} / \mathrm{mL}, 2.96 \pm 0.16 \log \mathrm{PFU} / \mathrm{mL}$ 로 유의적인 노로바이러스 농도 감소 효과를 보여 주었다. 그러나 바이러스 접종 이후 추출물 및 착즙물을 처리한 post-treatment에서는 5 가지 추출물 및 착즙물의 노로바이러 스 플라크 형성율 및 감소된 농도가 95.15-99.32\%와 0.04$0.37 \log \mathrm{PFU} / \mathrm{mL}$ 로 노로바이러스 농도의 감소는 보였으나, 대조구 대비 유의적인 차이를 나타내지는 않았다. 감 추출물 및 착즙물이 직접적으로 $\mathrm{MNV}$ 에 미치는 영향을 검토한 co-treatment 결과에서는 탄닌 함량에 따라 높은 항노로바이 러스 효과를 보여주었다. 결론적으로 감 착즙물의 경우, 추 출 수율은 낮았으나, 탄닌 함량과 항노로바이러스 효과는 가 장 높게 나타남을 확인할 수 있었다. 따라서, 향후 추가적인 연구를 통해 청도반시 착즙물의 항노로바이러스 대응 기능 성 소재로서의 활용 가능성을 부각시킬 수 있을 것으로 판단 된다.

\section{감사의 글}

본 연구는 2020년도 청도반시 항균, 항바이러스 효과 검증 학술연구용역에 의하여 수행되었습니다.

\section{Conflict of interests}

The authors declare no potential conflict of interest.

\section{ORCID}

Jaein Choe

https://orcid.org/0000-0003-1393-7516

Mi-Kyung Park

https://orcid.org/0000-0003-1182-6046

\section{References}

Akter MS, Ahmed M, Eun JB. Solvent effects on antioxidant properties of persimmon (Diospyros kaki L. cv. Daebong) seeds. Int J Food Sci Technol, 45, 2258-2264 (2010)

Arakawa H, Takasaki M, Tajima N, Fukamachi H, Igarashi T. Antibacterial activities of persimmon extracts relate with their hydrogen peroxide concentration. Biol Pharm Bull, 37, 1119-1123 (2014)

Bian LL, You SY, Park J, Yang SJ, Chung HJ. Characteristics of nutritional components in astringent persimmons according to growing region and cultivar. J Korean Soc Food Sci Nutr, 44, 379-385 (2015)

Bitler EJ, Matthews JE, Dickey BW, Eisenberg JNS, Leon JS. Norovirus outbreaks: A systematic review of commonly implicated transmission routes and vehicles. Epidemiol Infect, 141, 1563-1571 (2013)

Centers for Disease Control and Prevention. https://www.cdc. gov/norovirus/trends-outbreaks/worldwide.html (accessed February 2020)

Greening GE, Cannon JL. Human and animal viruses in food (including taxonomy of enteric viruses). In: Viruses in Foods, Goyal (Editor), Springer, New York, NY, USA, p 5-57 (2016)

Fukuchi K, Sakagami H, Okuda T, Hatano T, Tanuma SI, Kitajima $\mathrm{K}$, Inoue $\mathrm{Y}$, Inoue $\mathrm{S}$, Ichikawa $\mathrm{S}$, Nonoyama M, Konno K. Inhibition of herpes simplex virus infection by tannins and related compounds. Antiviral Res, 11, 285-297 (1989)

Hirneisen KA, Kniel KE. Comparing human norovirus surrogates: Murine norovirus and Tulane virus. J Food Prot, 76, 139-143 (2013)

Iwasawa A, Ayaki M, Niwano Y. Cell viability score (CVS) as a good indicator of critical concentration of benzalkonium chloride for toxicity in cultured ocular surface cell lines. Regul Toxicol Pharmacol, 66, 177-183 (2013) Jang IC, Jo EK, Bae MS, Lee HJ, Jeon GI, Park E, Yuk HG, Ahn GH, Lee SC. Antioxidant and antigenotoxic activities of different parts of persimmon (Diospyros 
kaki cv. Fuyu) fruit. J Med Plants Res, 4, 155-160 (2010)

Joshi SS, Su X, D'Souza DH. Antiviral effects of grape seed extract against feline calicivirus, murine norovirus, and hepatitis a virus in model food systems and under gastric conditions. Food Microbiol, 52, 1-10 (2015)

Kamimoto M, Nakai Y, Tsuji T, Shimamoto T, Shimamoto T. Antiviral effects of persimmon extract on human norovirus and its surrogate, bacteriophage MS2. J Food Sci, 79, M941-M946 (2014)

Kim BO, Cha WS, Ahn DH, Cho YJ. The change on cell wall composition and physiological characteristic of astringent persimmon fruits by gamma irradiation. Korean J Food Preserv, 22, 512-519 (2015)

Kim HJ, Park TS, Jung MS, Son JH. Study on the anti-oxidant and anti-inflammatory activities of sarcocarp and calyx of persimmon (Cheongdo Bansi). J Appl Biol Chem, 54, 71-78 (2011)

Kim YH, Lee SW, Kim HS, Lee SH, Song MK, Sung YC, Lee JJ. Inhibitory activities of tannins against reverse transcriptase and HIV-1 replication. Yakhak Hoeji, 39, 560-564 (1995)

Kim YW, You HJ, Lee S, Kim B, Kim DK, Choi JB, Kim JA, Lee HJ, Joo IS, Lee JS, Kang DH, Lee G, Ko GP, Lee SJ. Inactivation of norovirus by lemongrass essential oil using a norovirus surrogate system. J Food Prot, 80, 1293-1302 (2017)

Lee JH, Bae SY, Oh M, Seok JH, Kim S, Chung YB, K GG, Mun JY, Chung MS, Kim KH. Antiviral effects of black raspberry (Rubus coreanus) seed extract and its polyphenolic compounds on norovirus surrogates. Biosci Biotechnol Biochem, 80, 1196-1204 (2016)

Lee MH, Lee BH, Jung JY, Cheon DS, Kim KT, Choi C. Antiviral effect of Korean red ginseng extract and ginsenosides on murine norovirus and feline calicivirus as surrogates for human norovirus. J Ginseng Res, 35, 429-435 (2011)

Li D, Baert L, Zhang D, Xia M, Zhong W, Van Coillie E, Jiang $X$, Uyttendaele $M$. Effect of grape seed extract on human norovirus GII. 4 and murine norovirus 1 in viral suspensions, on stainless steel discs, and in lettuce wash water. Appl Environ Microbiol, 78, $7572-7578$ (2012)

Ministry of Food and Drug Safety. https://www.foodsafetyk orea.go.kr/portal/healthyfoodlife/foodPoisoningStat.do? menu_no=3724\&menu_grp=MENU_NEW02 (accessed
February 2020)

Patel MM, Hall AJ, Vinje J, Parashar UD. Noroviruses: A comprehensive review. J Clin Virol, 44, 1-8 (2009)

Price ML, Van Scoyoc S, Butler LG. A critical evaluation of the vanillin reaction as an assay for tannin in sorghum grain. J Agric Food Chem, 26, 1214-1218 (1978)

Randazzo W, Falco I, Aznar R, Sanchez G. Effect of green tea extract on enteric viruses and its application as natural sanitizer. Food Microbiol, 66, 150-156 (2017)

Richards GP. Critical review of norovirus surrogates in food safety research: Rationale for considering volunteer studies. Food Eenviron Virol, 4, 6-13 (2012)

Seo DJ, Jeon SB, Oh H, Lee BH, Lee SY, Oh SH, Jung JY, Choi C. Comparison of the antiviral activity of flavonoids against murine norovirus and feline calicivirus. Food Control, 60, 25-30 (2016)

Sim HJ, Kang JR, Kang MJ, Choi MH, Suh HJ, Shin JH. Changes in quality characteristic of immature flat persimmon (Diospyros kaki Thunb) during heat treatment aging. Korean J Food Preserv, 23, 301-309 (2016)

Su X, D'Souza DH. Grape seed extract for control of human enteric viruses. Appl Environ Microbiol, 77, 3982-3987 (2011)

Su X, Howell AB, D'Souza DH. Antiviral effects of cranberry juice and cranberry proanthocyanidins on foodborne viral surrogates-A time dependence study in vitro. Food Microbiol, 27, 985-991 (2010)

Sung SH, Kim KH, Jeon BT, Cheong SH, Park JH, Kim DH, Kwon HJ, Moon SH. Antibacterial and antioxidant activities of tannins extracted from agricultural byproducts. J Med Plants Res, 6, 3072-3079 (2012)

Trivedi TK, Desai R, Hall AJ, Patel M, Parashar UD, Lopman BA. Clinical characteristics of norovirusassociated deaths: A systematic literature review. Am J Infect Control, 41, 654-657 (2013)

Ueda K, Kawabata R, Irie T, Nakai Y, Tohya Y, Sakaguchi $\mathrm{T}$. Inactivation of pathogenic viruses by plant-derived tannins: Strong effects of extracts from persimmon (Diospyros kaki) on a broad range of viruses. PloS One, 8, e55343 (2013)

Yoo SA, Kim OK, Nam DE, Kim Y, Baek H, Jun W, Lee J. Immunomodulatory effects of fermented Curcuma longa L. extracts on RAW 264.7 cells. J Korean Soc Food Sci Nutr, 43, 216-223 (2014) 